\title{
On Heat-Resisting Steels and Alloys
}

\author{
By Toshio Fujita*
}

\section{Preface}

Recently heat-resisting steels and alloys have become very important because of the rapid progress of all sorts of heat engines (steam turbines, gas turbines, jet engines and so on), the hightemperature chemical industry and the atomic energy industry. Hereafter these industries will depend more and more upon the development of heat-resisting steels and alloys. For example, the annual rise in the working temperatures of heat engines is considered to go hand in hand with the development of high-temperature steels and alloys.

Recently the working temperature and pressure of steam engines have been rising rapidly. In Japan the maximum steam temperature and pressure were $450^{\circ} \mathrm{C}$ and $45 \mathrm{~kg} / \mathrm{cm}^{2}$ until about 1949 . But they reached $566^{\circ} \mathrm{C}$ and $170-190 \mathrm{~kg} / \mathrm{cm}^{2}$ in 1957, and for the future they should climb still higher, thus improving heat efficiency.

\section{Properties Necessary for Heat-Resisting Steels and Alloys}

The importance of properties necessary for heatresisting steels and alloys is not uniform for different uses, and so the following properties should be examined:

1) Mechanical properties at room-temperature

2) Mechanical properties at high temperature

3) Surface stability

4) Structural stability

5) Stability of properties at operating temperature

6) Property change by repetition of rapid heating and cooling

7) Formability at high temperature and at room temperature

8) Weldability

9) Physical properties at room temperature and high temperature

10) Economy

Creep characteristics, the most important mechanical property at high-temperature among the above listed properties, are described in the following chapter :

\section{Creep and Creep-Rupture Testing Machines}

The most important property for heat-resisting steels and alloys is a long-time, high-temperature, load-carrying ability. This long-time high-temperature strength can be found quantitatively by obtaining creep and creep-rupture curves.

Here omitting many papers already published about the creep and creep-rupture curves, a brief statement is made on research which the author and coworkers have been conducting with creep and creep-rupture testing machines since 1951 .

There are many varieties of methods for creep testing, but in general, a simple tension test is employed. The difficulty of creep testing, however, lies in the fact that the time required for the test is very long, the temperature of specimens must be kept constantly and correctly at high-temperature, and, moreover, the slight elongation must be measured correctly by micron units.

ASTM designation E 22-41 states that creep tests should be continued for about $10-20 \%$ of the expected life time of the materials, and that the results should not be extrapolated by those of less than $1 \%$ of the expected life time. After all, heatresisting steels and alloys for steam turbines or gas turbines, etc. which require a life of 100,000 hours, should be chosen based on the results of more than 10,000-20,000 hour creep tests, and these tests are considerably difficult in Japan since there are comparatively few creep testing machines.

Therefore it is needless to say that a large number of creep testing machines must be built as rapidly as possible in our country.

When we construct creep testing machines, the following points must be taken into consideration:

(1) The creep tester should be as small and simple as possible. The capacity of the creep tester should be $0.75-1.0 \mathrm{t}$.

(2) If the automatic electronic controller which the author and coworkers have developed is used, the temperature of a specimen can be maintained within an error of $\pm 1.0^{\circ} \mathrm{C}$ in a temperature range from 500 to $1,000^{\circ} \mathrm{C}$, without room temperature control throughout the year.

(3) The elongation should be measured by the dial gauge method or by the microtelescopic method, and not by the automatic electric recorder method.

(4) It is advisable that the creep tester be set on a place where it will vibrate as little as possible, but special vibration-proofing equipment is not necessary.

If creep testing machines are built upon consideration of the above points, one machine will cost about 250,000 yen (about $\$ 700$ ) per tester, and so it should not be so difficult to equip about one hundred stands of creep testing machines at one company in Japan.

The capacity and accuracy of the creep testing machines which are used now in the University of Tokyo are as follows:

1) Capacity of tester: $1500 \mathrm{~kg}$ (lever ratio $1: 10$ )

2) Load accuracy of tester:

less than $\pm 0.2 \%$ of total load

* Professor, University of Tokyo 
3) Accuracy of elongation measurement: $1 \mu(1 / 1000 \mathrm{~mm})$

4) Accuracy of temperature control:

$$
\pm 1.0^{\circ} \mathrm{C} \text { at } 500-1000^{\circ} \mathrm{C}
$$

5) Temperature difference between top and bottom of the specimens: less than $1^{\circ} \mathrm{C}$

6) Accuracy of temperature measurement: less than $0.2^{\circ} \mathrm{C}$ error

The author and coworkers have also investigated creep rupture testers and have constructed an accurate as well as a cheap tester. Photo 1 shows 20 stands of creep rupture testers $(180,000$ yen $=$ $\$ 500$ per tester) which were set up in 1957.

\section{Kinds and Properties of Heat-Resisting Steels and Alloys}

There are many kinds of heat-resisting steels and alloys, but herein are included $12 \%$ chromium heat-resisting steels ${ }^{2): 3}$ and precipitation hardening austenitic heat-resisting steels, which the author and coworkers have investigated. Moreover nickel-base heat-resisting alloys and cobaltbase heat-resisting alloys, which we have also investigated, have made remarkable progress recently.

\section{1. $12 \%$ Chromium Heat-Resisting Steels}

$12 \%$ chromium heat-resisting steel, to which Mo, $\mathrm{W}, \mathrm{V}, \mathrm{Nb}$, etc. have been added in order to increase high-temperature strength, is used widely, not only for the rotors of jet engines, but also for the turbine blades of super high-temperature steam turbines and gas turbines.

These typical steels are shown in Table 1. This $12 \%$ chromium heat-resisting steel has the following superior characteristics:

a) Under $550^{\circ} \mathrm{C}$, it has higher creep strength, tensile strength and yield point than austenitic heat-resisting steels.

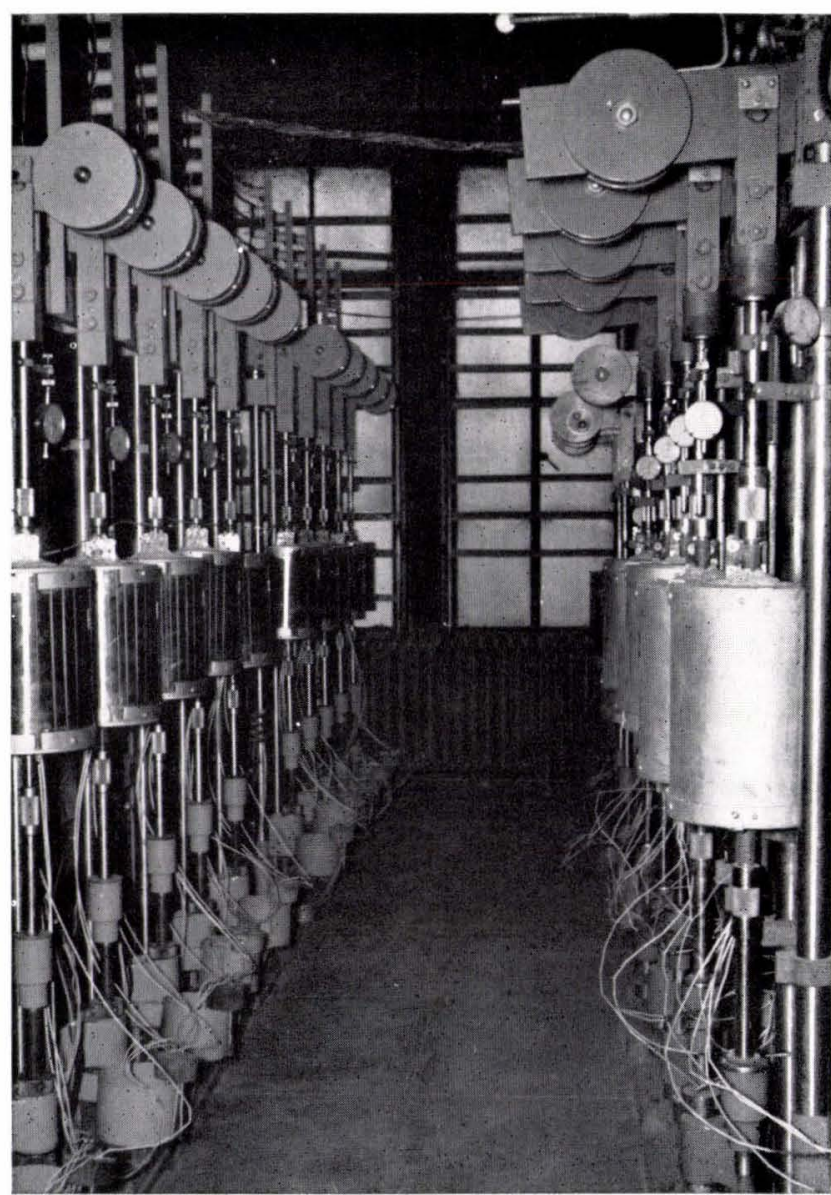

Photo 1. View of a series of creep-rupture testing machines

Table 1. Chemical composition and heat treatment of typical $12 \%$ chromium heat-resisting steels

\begin{tabular}{|c|c|c|c|c|c|c|c|c|c|c|c|}
\hline \multirow{2}{*}{ Names of steel $*$} & \multirow{2}{*}{ C } & \multirow{2}{*}{$\mathrm{Si}$} & \multirow{2}{*}{ Mn } & \multirow{2}{*}{$\mathrm{Cr}$} & \multirow{2}{*}{ Mo } & \multirow{2}{*}{ W } & \multirow{2}{*}{ V } & \multirow{2}{*}{$\mathrm{Nb}$} & \multirow{2}{*}{$\begin{array}{l}\text { Other } \\
\text { elements }\end{array}$} & \multicolumn{2}{|c|}{ Heat treatment } \\
\hline & & & & & & & & & & Quenching & Tempering \\
\hline H 46 (E.) & 0.15 & 0.4 & 0.6 & 11.5 & 0.45 & & 0.30 & 0.25 & & $1150^{\circ} \mathrm{C}, \quad$ A.C. & $650^{\circ} \mathrm{C}$, A.C. \\
\hline $\operatorname{Rex} 448$ (E.) & 0.12 & 0.2 & 0.9 & 10.5 & 0.75 & & 0.15 & 0.45 & & $1150^{\circ} \mathrm{C}, \quad$ O.Q. & $650^{\circ} \mathrm{C}$, A.C. \\
\hline HGT 4 (E.) & 0.17 & 0.5 & 1.0 & 11.5 & 0.6 & & 0.20 & 0.20 & $0.03 \stackrel{\mathrm{B}}{\mathrm{N}}$ & $1150^{\circ} \mathrm{C}, \quad$ O.Q. & $650^{\circ} \mathrm{C}$, A.C. \\
\hline 422 (A.) & 0.22 & 0.4 & 0.6 & 12.0 & 1.00 & 1.00 & 0.25 & & $0.70 \mathrm{Ni}$ & $1060^{\circ} \mathrm{C}, \quad$ O.Q. & $650^{\circ} \mathrm{C}$, A.C. \\
\hline $422 \mathrm{M}$ (A.) & 0.28 & 0.3 & 0.8 & 12.0 & 2.25 & 1.70 & 0.50 & & $0.20 \mathrm{Ni}$ & & - \\
\hline Greek Ascolloy (A.) & 0.12 & 0.3 & 0.4 & 13.0 & & 3.0 & & & $2.0 \mathrm{Ni}$ & $1100^{\circ} \mathrm{C}, \quad$ O.Q. & $650^{\circ} \mathrm{C}$, A.C. \\
\hline Cobalt Ascolloy (A.) & 0.20 & 0.3 & 0.4 & 12.25 & & 3.0 & 0.25 & & $5.0 \mathrm{Co}$ & & \\
\hline Lapelloy (A.) & 0.30 & 0.25 & 1.0 & 12.0 & 2.75 & - & 0.25 & - & $0.30 \mathrm{Ni}$ & $1100^{\circ} \mathrm{C}, \quad$ O.Q. & $650^{\circ} \mathrm{C}$, A.C. \\
\hline Lapelloy C (A.) & 0.22 & 0.25 & 0.8 & 11.5 & 2.75 & & & & $\begin{array}{l}2.0 \mathrm{Cu} \\
0.08 \mathrm{~N}\end{array}$ & & - \\
\hline 419 (A.) & 0.25 & 0.30 & 1.0 & 11.5 & 0.5 & 2.5 & 0.4 & & $(0.05 \mathrm{~N})$ & $\stackrel{1050^{\circ} \mathrm{C}}{\sim 1150^{\circ} \mathrm{C}, \mathrm{O} . \mathrm{Q} .}$ & $650^{\circ} \mathrm{C}$, A.C. \\
\hline MTS-1 (G.) & 0.22 & 0.3 & 0.6 & 12.5 & 1.2 & - & & & $0.4 \mathrm{Ni}$ & 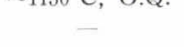 & \\
\hline MTS-4 (G.) & 0.18 & 0.3 & 0.5 & 12.0 & 1.0 & 0.5 & 0.25 & - & $0.6 \mathrm{Ni}$ & - & - \\
\hline TAF (J.) & 0.16 & 0.5 & 0.8 & 11.5 & 1.0 & & 0.20 & 0.20 & $\begin{array}{l}0.04 \mathrm{~B} \\
0.015 \mathrm{~N}\end{array}$ & $1150^{\circ} \mathrm{C}, \quad$ O.Q. & $700^{\circ} \mathrm{C}$, A.C. \\
\hline
\end{tabular}


b) It excels austenitic heat-resisting steels in case of ingot-making, forgeability and machinability.

c) Its price ranges from one-third to one-fourth that of the same weight of austenitic heat-resisting steels, as it contains no nickel nor cobalt.

d) As its coefficient of thermal expansion is small and its thermal conductivity is large, it produces small amounts of thermal stress.

e) Austenitic heat-resisting steel has a low yield point in general which must be raised by "hot-cold working", while $12 \%$ chromium heat-resisting steel has a yield point high enough to be treated by ordinary quenching and tempering.

In short, if one lays stress on economic aspects, the $12 \%$ chromium heat-resisting steel has a marked advantage over the austenitic heat-resisting steel, as the best heat-resisting steel for temperatures below $600-650^{\circ} \mathrm{C}$.

The most famous steel among these $12 \%$ chromium heat-resisting steels is Jessop H46. H46 was investigated on the basis of $\mathrm{H} 40 \quad(0.2 \% \mathrm{C}, 3 \%$ Cr, $0.5 \%$ Mo, $0.5 \% \mathrm{~W}, 0.75 \% \mathrm{~V})$. That is, as longtime oxidation resistance above $600^{\circ} \mathrm{C}$ cannot be obtained at $3 \%$ chromium of $\mathrm{H} 40$, the chromium content was increased to $11-12 \%$. But the creep strength of steels containing the same amounts of alloying element as $\mathrm{H} 40$ falls, on the contrary. Therefore, by replacing wolfram (tungsten) of H40 alloying elements with niobium, the creep strength becomes a little higher than that of $\mathrm{H} 40$.

Moreover as the coagulation of vanadium carbide $\left(\mathrm{V}_{4} \mathrm{C}_{3}\right)$ in $12 \%$ chromium heat-resisting steel proceeds remarkably near the operating temperature $\left(550-600^{\circ} \mathrm{C}\right)$, the creep strength can be increased by lowering the vanadium content from $0.7 \%$ to $0.3 \%$. The effects of this alloying element are shown in Table 2. The creep-rupture strength of this H46 does not fall for a long-time $(10,000$ hours ) at temperatures of $400-550^{\circ} \mathrm{C}$, but the creeprupture strength at 1,000 hours is lowered remarkably at temperatures of $600-700^{\circ} \mathrm{C}$. It is because the addition of nearly $0.05 \%$ nitrogen, which is added in order to raise the creep-rupture strength at temperatures of $400-500^{\circ} \mathrm{C}$, has a very bad effect on the long-time creep-rupture strength at temperatures of $600-700^{\circ} \mathrm{C}$.

In the United States, $12 \%$ chromium heat-resisting steel has also been investigated, and 422, 419, Ascolloy and so on are presented. Any of these creep-rupture strengths are by far inferior to $\mathrm{H} 46$ or Rex 448, etc. which have been developed in the United Kingdom. It is presumed that the carbide coagulates actively above $600^{\circ} \mathrm{C}$ and consequently the creep-rupture strength falls rapidly because the amount of alloying element in these heat-resisting steels is more than $2 \%$ and the amount of carbon is $0.20-0.25 \%$.

The author and coworkers have investigated since 1952 the influence of alloying elements such as Mo, W, V, Nb, Ti, B, N, C and so on, and different heat treatments; and in 1956 we discovered a very strong $12 \%$ chromium heat-resisting steel TAFsteel (Tokyo University-Akutagawa-Fujita), in which $0.8 \%$ Mo, $0.15 \% \mathrm{~V}, 0.15 \%$ Nb, $0.04 \% \mathrm{~B}$, $0.015 \% \mathrm{~N}$, are added to $12 \%$ chromium steel. This TAF steel excels Timken 16-25-6, G 18 B, etc., which are famous as austenitic heat-resisting steels, in creep strengths under $650^{\circ} \mathrm{C}$.

The creep-rupture strength of typical $12 \%$ chromium heat-resisting steels is shown in Table 3. That of TAF steel and H46 is shown in Fig. 1. As the result, TAF steel is found to be greatly superior to H46 in long-time creep-rupture strength.

Recently in Jessop-Saville Ltd. in the United Kingdom, H53,4) H58, etc., which are the improved steel of H46, and in which creep strength at temperatures of $500-550{ }^{\circ} \mathrm{C}$ is increased, were presented. The chemical composition and creep-rupture strength of these is shown in Table 4. In this heatresisting steel, $7-8 \%$ cobalt is added for the purpose of preventing the appearance of 8-ferrite, which is apparently caused by that amount of the alloying element of $12 \%$ chromium heat-resisting steel increased to raise the creep strength. From investigation by the author and coworkers, however, the long-time creep strength near temperatures of 600 $650^{\circ} \mathrm{C}$ of these types of heat-resisting steel is pre-

Table 2. Effect of alloy additions on creep resistance of $12 \% \mathrm{Cr}, 0.5 \%$ Mo type steel*

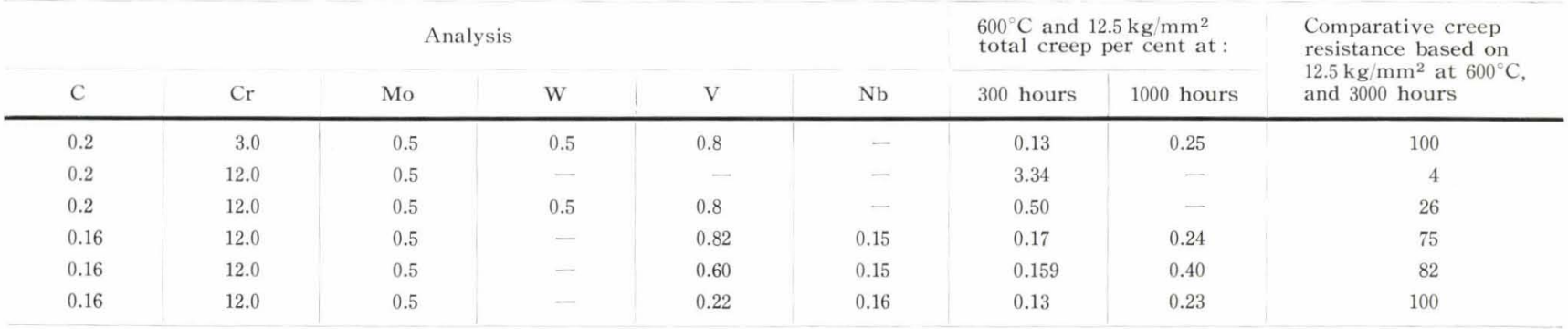

* Solution treated at $1250^{\circ} \mathrm{C}$, and aged at $650^{\circ} \mathrm{C}$ 
sumed to be greatly decreased.

\section{Precipitation-Hardening Austenitic Heat-Resisting Steels}

A286, (1) (5) Discaloy, W545,7) Unitemp 212,8)9) and so on belong to this type. In all of these heatresisting steels, titanium and aluminium are added to the austenite matrix in order to promote precipitation hardening and to raise the high-temperature strength, and moreover molybdenum is added in order to strengthen the austenite matrix. The

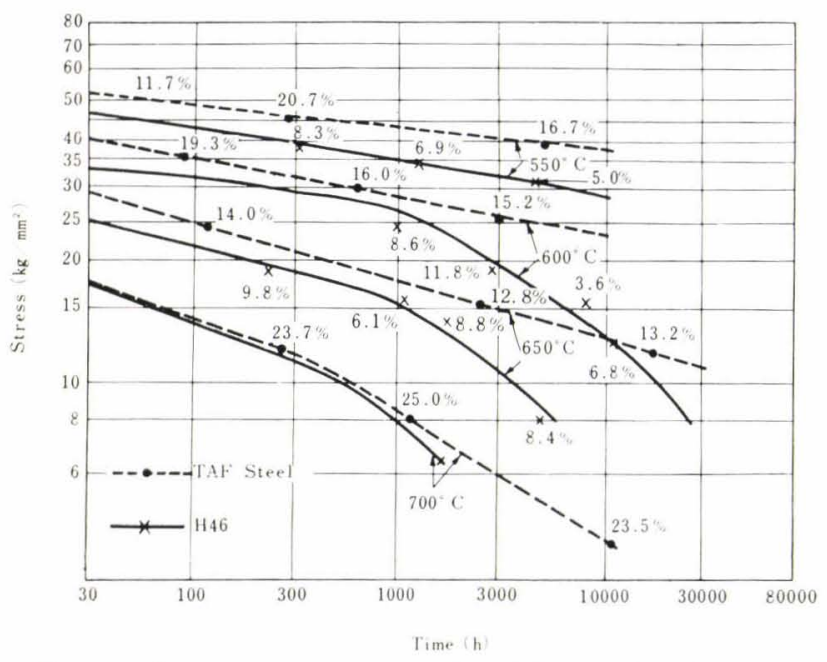

Fig. 1. Stress-rupture curves for TAF steel and Jessop H 46 chemical composition and creep-rupture strength of these heat-resisting steels are shown in Table 5. Besides, 1000 hours rupture-strength of the typical precipitation hardening type and the "hotcold working" type heat-resisting steels (Timken 16-25-6, 19-9 DL, etc.) are shown in Fig. 2.

As a result, it is apparent that the precipitationhardening type heat-resisting steel has a higher strength than the "hot-cold working" type heatresisting steel in a range from room temperature to high temperature. Moreover, when one manufactures comparatively large forged materials such as rotors and dises by using the "hot-cold working" type heat-resisting steel, it is fairly difficult to gain uniform mechanical properties by "hot-cold working"; but it counts for nothing when one uses the precipitation-hardening type heat-resisting steel.

But the precipitation-hardening type heat-resisting steel contains the element to be oxidized and nitrided in the process of melting, such as titanium or aluminium, which is the most important element of the mechanical properties. Moreover, as heatresisting steel of this type is apt to cause a defect or a segregation in the ingot, the yield of ingot is low.

Against these defects, however, a vacuum melting method with a consumable electrode was used recently, proving sound ingots can be obtained without being influenced by the air. This method is being put to practical use. ${ }^{10)}$

Table 3. Rupture strengths $*$ of $12 \%$ chromium heat-resisting steels

Strength unit: $\mathrm{kg} \mathrm{mm}^{2}$ )

\begin{tabular}{|c|c|c|c|c|c|c|c|c|c|c|}
\hline \multirow{2}{*}{ Names of steel } & \multicolumn{2}{|c|}{$550^{\circ} \mathrm{C}$} & \multicolumn{2}{|c|}{$600^{\circ} \mathrm{C}$} & \multicolumn{3}{|c|}{$650^{\circ} \mathrm{C}$} & \multicolumn{2}{|c|}{$700 \mathrm{C}$} & \multirow{2}{*}{ Presumed patentees } \\
\hline & 100 & 1000 & 100 & 1000 & 100 & 1000 & 10000 & 100 & 1000 & \\
\hline H 46 & 42.2 & $\approx 6.0$ & 32.0 & 26.5 & 22.0 & 15.0 & $(6.0) * *$ & 14.0 & 7.9 & Jessop-Saville \\
\hline HGT-4 & $>41.5$ & $>36.0$ & 32.2 & 25.9 & 25.9 & 16.8 & $(11.0) * *$ & 14.9 & 7.1 & Hadfield \\
\hline $\operatorname{Rex} 448$ & 44.0 & 40.6 & 30.5 & 25.9 & 22.0 & 14.9 & $(5.0) * *$ & & & Firth Vickers \\
\hline 422 & 40.0 & 36.0 & 28.0 & 22.0 & 17.5 & 11.9 & & & & Crucible Steel \\
\hline 419 & & & 37.0 & 29.0 & 22.4 & 13.3 & $(7.7) * *$ & & & Allegheny Ludlum \\
\hline TAF & 51.0 & 45.0 & 36.0 & 31.0 & 25.0 & 19.3 & 13.3 & 13.3 & 9.5 & $\begin{array}{l}\text { Hitachi Metal } \\
\text { Industries Co. }\end{array}$ \\
\hline
\end{tabular}

* For rupture in 100,1000 and $10000 \mathrm{hr} \quad * *$ Extrapolated value

Table 4. Comparison of chemical composition and mechanical properties of chromium martensitic steels

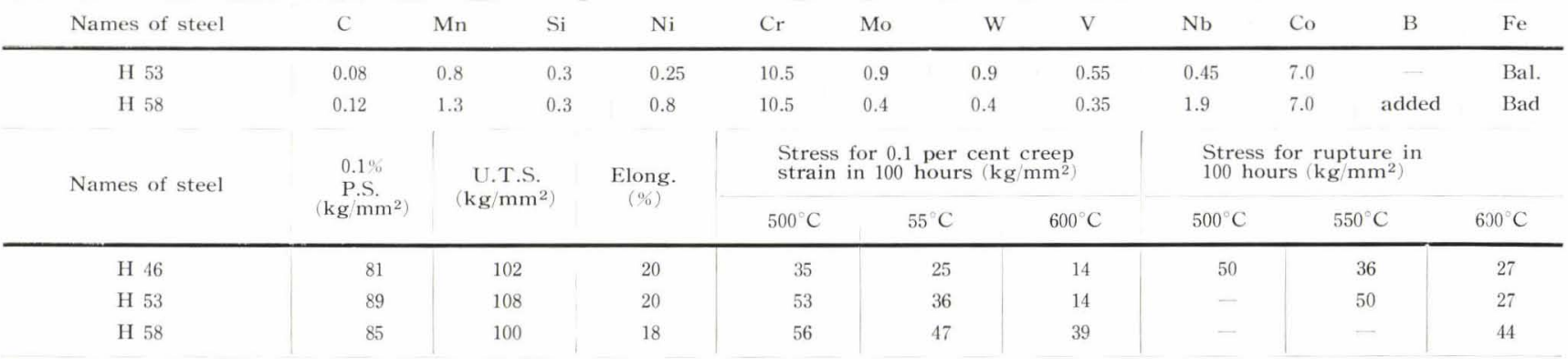


Table 5. Chemical composition, heat treatment and rupture strength $*$ of the precipitationhardening heat-resisting steels

(Strength unit: $\mathrm{kg} / \mathrm{mm}^{2}$ )

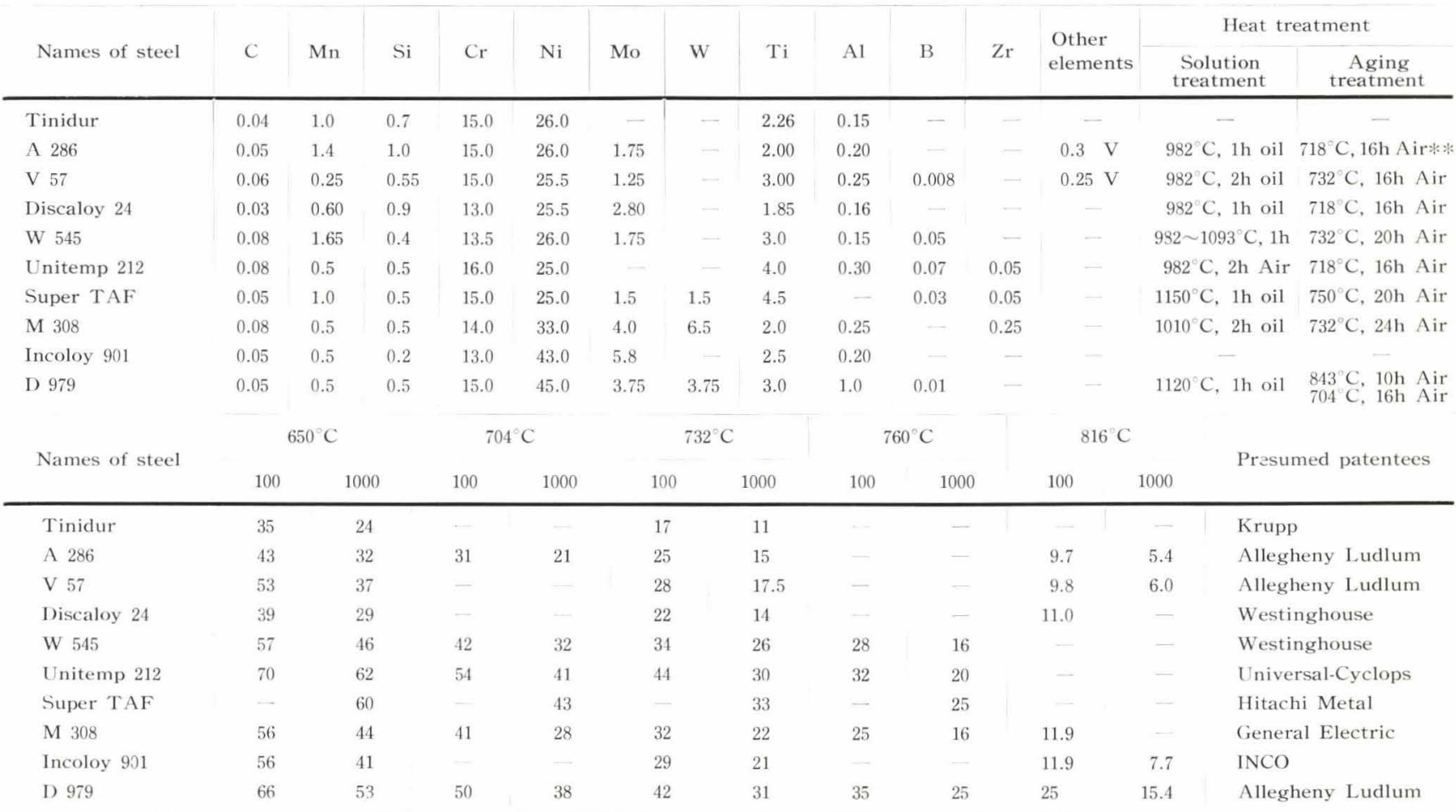

* For rupture in 100 and $1000 \mathrm{hr} \quad * * \mathrm{Air}=$ air cool

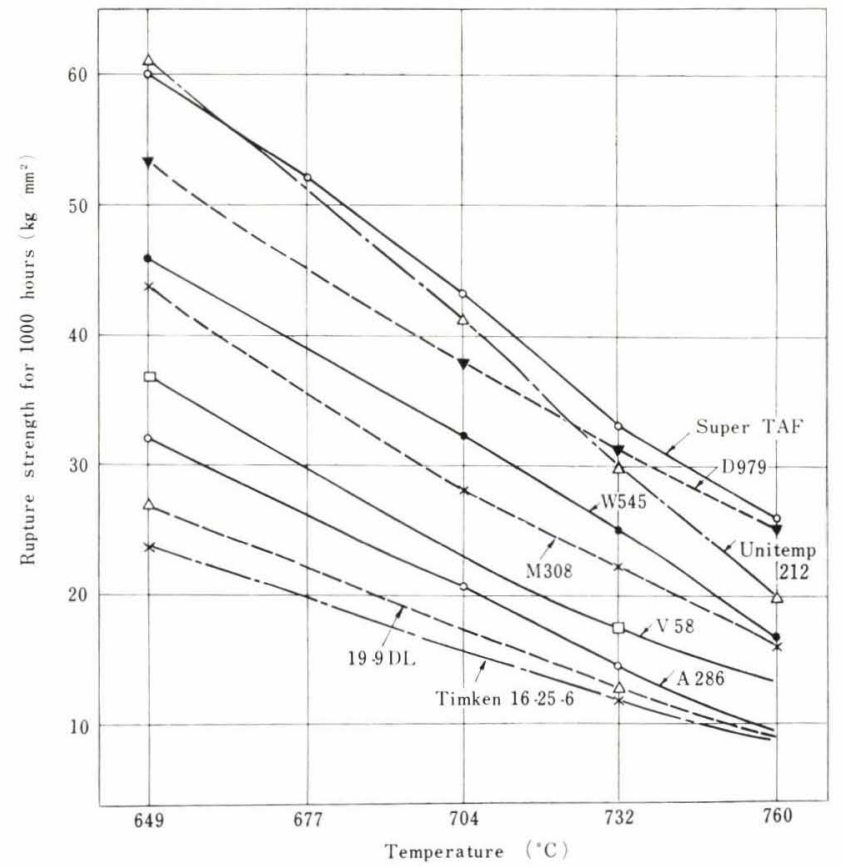

Fig. 2. 1000 hours rupture strength of austenitic heatresisting steels

A286 is an improved steel of Tinidur developed in Germany, to which $0.3 \%$ vanadium is added to promote precipitation hardening, and molybdenum is added to strengthen the austenite matrix. The heat treatment of this heat-resisting steel consists of treatment for 1 hour at $980^{\circ} \mathrm{C}$, followed by oil quenching in order to dissolve $\mathrm{Ni}_{3}(\mathrm{Ti}, \mathrm{Al}$ ) into the austenite matrix, and thereafter treatment for 16 hours at $720^{\circ} \mathrm{C}$ for precipitation and to cause precipitation hardening.

This is now used for rotors of jet engines, afterburners and bolts. Recently A286 was further improved by adding $3 \%$ titanium, like V57, thus increasing its high-temperature strength.

W545, ${ }^{11)}$ which was developed by the Westinghouse Electric Corporation, is the improved steel of Discaloy 24. The molybdenum content in these heat-resisting steels is decreased from $3.0 \%$ to $1.5 \%$ in order to stabilize the austenite matrix, the titanium content is increased from $1.8 \%$ to $3.0 \%$, and between $0.05 \%$ and $0.08 \%$ boron is added, which raises the high-temperature strength remarkably. The effects of adding boron are as follows:

(1) The boron atom is about three-fourths the size of the substitutional element, Fe, Cr, Co, Ni and Mn, etc., but somewhat larger than the interstitials, H, C and N. Thus, it would appear that boron could not be either a substitutional or an interstitial element conveniently, and so internal 
stress would be introduced into the lattice.

(2) The boron is concentrated mainly on the grain boundaries and serves to decrease imperfections existing on the grain boundaries. Moreover it controls precipitation hardening near the grain boundaries, thus preventing brittle fractures at the grain boundaries.

As a result, the addition of boron raises the hightemperature strength remarkably and also raises the rupture elongation.

As this heat-resisting steel has superior strength, ductility and oxidation resistance, it is being used widely for rotors, discs and bolts of gas turbines and jet engines.

Unitemp 212, which was recently presented by the Universal Cyclop Steel Corporation, is quite superior in creep strength near temperatures between $650^{\circ} \mathrm{C}$ and $700^{\circ} \mathrm{C}$. This is due to the addition of $4 \%$ titanium. But near temperatures between $750^{\circ} \mathrm{C}$ and $800^{\circ} \mathrm{C}$, its creep strength falls as $\mathrm{Ni}_{3}$ $\mathrm{Ti}$ begins to coagulate rapidly.

The author and coworkers have investigated a precipitation-hardening heat-resisting steel of this type, and found that by adding Mo, W, Ti, B, and $\mathrm{Zr}$, etc. appropriately to the $15 \mathrm{Cr}-25 \mathrm{Ni}$ type austenitic steel, we succeeded in discovery of a superior heat-resisting steel (Super TAF steel), of which the creep-rupture strength at $650^{\circ} \mathrm{C}$, for $1000 \mathrm{~h}$ is $60 \mathrm{~kg} / \mathrm{mm}^{2}$, and the rupture elongation is $10 \%$. This research is now being advanced.

On the other hand, there is a new alloy D979,12) intermediate between the precipitation-hardening type heat-resisting steels and nickel-base heatresisting alloys. As the coefficient of thermal expansion for this alloy is smaller than that of ordinary austenitic steel, the thermal stress produced when it is used for rotors and blades of jet engines and gas turbines, is small and very convenient. In this alloy, precipitation hardening is effected by titanium or aluminium, etc.; the austenite matrix is strengthened by molybdenum and wolfram, etc.; and the high-temperature strength is raised by $1010^{\circ} \mathrm{C}$, one hour treatment followed by oil quenching, and then by a two-stepped two aging operation (consisting of $845^{\circ} \mathrm{C}, 6 \mathrm{hr}$ treatment followed by air cooling, and $700^{\circ} \mathrm{C}, 16 \mathrm{hr}$ treatment followed by air cooling). By aging at $845^{\circ} \mathrm{C}$, precipitation takes place near the grain boundaries, thus increasing the ductility, and by aging at $700^{\circ} \mathrm{C}$, precipitation takes place in the austenite matrix, thus raising the creep-rupture strength. Though this alloy contains a considerable amount of iron, it has a creep-rupture strength as strong as M252 and Waspaloy of the nickel-base heat-resisting alloys, and now 3 ton ingots are being manufactured by the double vacuum melting method in the United States.

\section{Nickel-Base Heat-Resisting Alloys}

The typical nickel-base heat-resisting alloys are shown in Table 6. These heat-resisting alloys have their origin in Nimonic $80 \mathrm{~A}$ which was investigated in the United Kingdom at the time of World War II. For Nimonic $80 \mathrm{~A}$, high-temperature strength is remarkably raised by adding titanium and aluminium, etc. to $75 \mathrm{Ni}-20 \mathrm{Cr}$ Nicrome alloy, and it can be additionally raised by adding cobalt and molybdenum, etc. These heat-resisting alloys are now used for the blades of gas turbines and jet engines. Previously cobalt-base heat-resisting alloys such as S816, Vitallium, and so on had been used for these blades, but nowadays nickel-base alloy is mostly used as it is more advantageous to the design of the turbines. The creep-rupture strength of these nickel-base heat-resisting alloys is shown in Fig $3 .^{13)}$ The axis of abscissa is shown by parameter $\mathrm{P}=\mathrm{T}(20+\log \mathrm{t})$, where $\mathrm{T}$ shows absolute temperature $\left({ }^{\circ} \mathrm{K}\right)$ and $\mathrm{t}$ shows time $(\mathrm{h})$.

Nickel-base heat-resisting alloys have made great advances, the tendency of which is considered to be as follows:

(1) Addition of cobalt

The fact that the addition of cobalt raises the high-temperature strength is already admitted in the progress from Nimonic $80 \mathrm{~A}$ to Nimonic 90 . The addition of cobalt not only raises the strength of austenite matrix, but also raises the temperature of solubility limit of elements such as titanium and aluminium. ${ }^{14) 15}$ ) Consequently, by addition of cobalt, the overaging temperature is raised, and so strength can be maintained up to high temperatures.

(2) Increase of $\mathrm{Ti}$ and $\mathrm{Al}$ contents

The gradual increase of titanium and aluminium content is obvious, seeing the advance to Nimonic 90, 100, 115.9) For example, the titanium and aluminium content of Nimonic $115(9.0 \%)$ corresponds to two and a half times that of Nimonic 90. However, when titanium and aluminium are added to this nickel-base alloy, a forging crack is apt to be caused, so that the manufacture is attended with much difficulty. Therefore, the manufacture of Nimonic 115 is not possible unless the method of vacuum melting is utilized.

(3) Addition of molybdenum

The notable tendency in the progress to Nimonic 100 from Nimonic 95 is the addition of molybdenum. That is, for all of Nimonic 100, 105 and 115, molybdenum has been added. The molybdenum content of these alloys is about $5 \%$, but that of M252, René 41, etc. is $10 \%$. These nickel-base alloys with high molybdenum content precipitate a great deal of $\mathrm{M}_{6} \mathrm{C}$ type carbide in addition to $\mathrm{Ni}_{3}$ ( $\mathrm{Ti}, \mathrm{Al}$ ). 
Table 6. Chemical composition and heat treatment of nickel-base heat-resisting alloys

\begin{tabular}{|c|c|c|c|c|c|c|c|c|c|c|c|c|c|}
\hline Names of alloy & $\mathrm{C}$ & Mn & $\mathrm{Si}$ & $\mathrm{Cr}$ & $\mathrm{Ni}$ & Co & Mo & W & $\mathrm{Ti}$ & $\mathrm{Al}$ & B & $\begin{array}{l}\text { Other } \\
\text { elements }\end{array}$ & Heat treatment \\
\hline Nimonic $80 \mathrm{~A}$ & 0.05 & $1.0^{*}$ & $1.0^{*}$ & 20 & 76 & - & - & - & 2.3 & 1.0 & - & - & 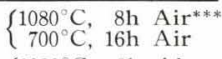 \\
\hline Nimonic 90 & 0.08 & $1.0^{*}$ & $1.0^{*}$ & 20 & 58 & 16 & & - & 2.4 & 1.4 & - & & $\left\{\begin{array}{r}1080^{\circ} \mathrm{C}, 8 \mathrm{~h} \text { Air } \\
700^{\circ} \mathrm{C}, 16 \mathrm{~h} \text { Air }\end{array}\right.$ \\
\hline Nimonic 95 & 0.08 & $1.0^{*}$ & $1.0^{*}$ & 20 & 58 & 16 & - & - & 2.5 & 1.6 & - & & $\left\{\begin{aligned} 1150^{\circ} \mathrm{C}, & 4 \mathrm{~h} \text { Air } \\
1080^{\circ} \mathrm{C}, & 7 \mathrm{~h} \text { Air } \\
700^{\circ} \mathrm{C}, & 16 \mathrm{~h} \mathrm{Air}\end{aligned}\right.$ \\
\hline Nimonic 100 & $0.3^{*}$ & & 0.5 & 11 & 47 & 20 & 3.5 & - & 1.5 & 5.0 & - & & $\left\{\begin{aligned} & 1200^{\circ} \mathrm{C}, 1.5 \mathrm{~h} \text { Air } \\
& 850^{\circ} \mathrm{C}, 16 \mathrm{~h} \mathrm{Air}\end{aligned}\right.$ \\
\hline Nimonic 105 & $0.2^{*}$ & - & & 12 & Bal. & 20 & 5.0 & & 1.2 & 4.5 & & - & $\left\{\begin{aligned} 1200^{\circ} \mathrm{C}, & 1.5 \mathrm{~h} \mathrm{Air} \\
900^{\circ} \mathrm{C}, & 16 \mathrm{~h} \mathrm{Air}\end{aligned}\right.$ \\
\hline Nimonic 115 & $0.2^{*}$ & & & 15 & Bal. & 15 & 3.5 & & 4.0 & 5.0 & 一 & & - \\
\hline Udimet 500 & 0.08 & $0.75^{*}$ & $0.75^{*}$ & 19 & Bal. & 20 & 4 & & 3.0 & 2.8 & 0.01 & - & $\left\{\begin{array}{r}1180^{\circ} \mathrm{C}, \quad 2 \mathrm{~h} \text { Air } \\
840^{\circ} \mathrm{C}, 16 \mathrm{~h} \text { Air }\end{array}\right.$ \\
\hline Udimet 600 & 0.10 & & & 18 & Bal. & 17 & 4 & & 2.8 & 4.0 & 0.04 & - & - \\
\hline Udimet 700 & $0.15^{*}$ & & & 15 & Bal. & 18 & 5 & & 3.5 & 4.3 & 0.10 & - & \\
\hline Inco 700 & 0.13 & 0.08 & 0.25 & 15 & 46 & 29 & 3 & & 2.2 & 3.0 & & 一 & $\left\{\begin{aligned} 1180^{\circ} \mathrm{C}, & 2 \mathrm{~h} \text { Air } \\
870^{\circ} \mathrm{C}, & 4 \mathrm{~h} \text { Air }\end{aligned}\right.$ \\
\hline Inco 713 & 0.12 & 0.15 & 0.4 & 13 & Bal. & & 4.5 & & 0.5 & 6.0 & & $2.0 \mathrm{Nb}$ & - \\
\hline Inco $713(\mathrm{C})^{* * *}$ & $0.20^{*}$ & $1.0^{*}$ & $1.0^{*}$ & 12 & Bal. & 8 & 4.3 & $0.12 \mathrm{Zr}$ & 1.0 & 7.6 & 0.012 & $2.0 \mathrm{Nb}$ & - \\
\hline Waspaloy & 0.07 & 0.7 & 0.4 & 19 & Bal. & 14 & 4 & & 3.0 & 1.3 & 0.006 & 一 & $\left\{\begin{array}{r}1080^{\circ} \mathrm{C}, \text { 4h Air } \\
840^{\circ} \mathrm{C}, 24 \mathrm{~h} \mathrm{Air} \\
760^{\circ} \mathrm{C}, 16 \mathrm{~h} \mathrm{Air}\end{array}\right.$ \\
\hline GMR-235 (C)** & 0.15 & 0.25 & $0.6^{*}$ & 15 & Bal. & & 5.5 & & 2.0 & 3.0 & 0.05 & - & - \\
\hline Astroloy & 0.06 & & & 15 & Bal. & 15 & 5.3 & - & 3.5 & 4.4 & 0.03 & - & \\
\hline Unitemp. AF 1753 & 0.24 & 0.05 & 0.10 & 16 & Bal. & 7 & 1.6 & 8.5 & 3.2 & 1.9 & 0.08 & $\begin{array}{l}9.0 \mathrm{Fe} \\
0.06 \mathrm{Zr}\end{array}$ & \\
\hline M 252 & 0.15 & 0.5 & 0.5 & 20 & Bal. & 10 & 10 & - & 3.0 & 1.0 & & & $\left\{\begin{array}{r}1070^{\circ} \mathrm{C}, \text { 4h Air } \\
760^{\circ} \mathrm{C}, 15 \mathrm{~h} \text { Air }\end{array}\right.$ \\
\hline René 41 & 0.09 & & & 19 & Bal. & 10 & 10 & - & 3.0 & 1.5 & 0.01 & & $\left\{\begin{aligned} 1180^{\circ} \mathrm{C}, & 1 / 2 \mathrm{~h} \mathrm{Air} \\
760^{\circ} \mathrm{C}, & 16 \mathrm{~h} \mathrm{Air}\end{aligned}\right.$ \\
\hline $\mathrm{B} \& \mathrm{~B}(\mathrm{C})^{* *}$ & 0.08 & & - & 15 & 45 & 30 & 5 & - & 2.5 & 3.0 & 0.5 & - & \\
\hline I- $1360(C)^{* *}$ & 0.10 & & - & 10 & 71 & - & 5 & - & - & 6.0 & 0.3 & $\begin{array}{l}4.5 \mathrm{Fe} \\
2.0 \mathrm{Nb}\end{array}$ & - \\
\hline $\operatorname{DCM}(\mathrm{C})^{* *}$ & $0.08^{*}$ & 0.10 & 0.15 & 15 & Bal. & - & 5.3 & - & 3.5 & 4.6 & 0.08 & $\begin{array}{l}5.0 \mathrm{Fe} \\
0.1 \mathrm{Cu}^{*}\end{array}$ & $\left\{\begin{array}{rll}1150^{\circ} \mathrm{C}, & \text { 1h } & \text { Air } \\
1060^{\circ} \mathrm{C}, & 2 \mathrm{~h} \mathrm{Air} \\
845^{\circ} \mathrm{C}, & \text { 4h } & \text { Air }\end{array}\right.$ \\
\hline Nicrotung $(\mathrm{C})^{* *}$ & 0.10 & & & 12 & Bal. & 10 & - & 8 & 4.0 & 4.0 & 0.05 & $0.05 \mathrm{Zr}$ & $\left\{\begin{aligned} 1150^{\circ} \mathrm{C}, & \text { 1h } \mathrm{Air} \\
1060^{\circ} \mathrm{C}, & 2 \mathrm{~h} \text { Air } \\
845^{\circ} \mathrm{C}, & 4 \mathrm{~h} \text { Air }\end{aligned}\right.$ \\
\hline G $64(C)^{* *}$ & 0.12 & 0.4 & 0.4 & 11 & Bal. & - & 3.0 & 4.0 & $2.0 \mathrm{Nb}$ & 6.0 & added & $4.5 \mathrm{Fe}^{*}$ & - \\
\hline G 70 & 0.1 & & & 15 & Bal. & 19 & 6.0 & & 3.5 & 4.2 & added & $\mathrm{Zr}$ added & - \\
\hline Nimocast $258(\mathrm{C})^{* *}$ & 0.22 & 0.25 & 0.25 & 10 & Bal. & 20 & 5 & & 3.7 & 4.8 & & - & - \\
\hline
\end{tabular}

* Maximum $* *(\mathrm{C})=$ cast $\quad * * * \quad$ Air $=$ air cool

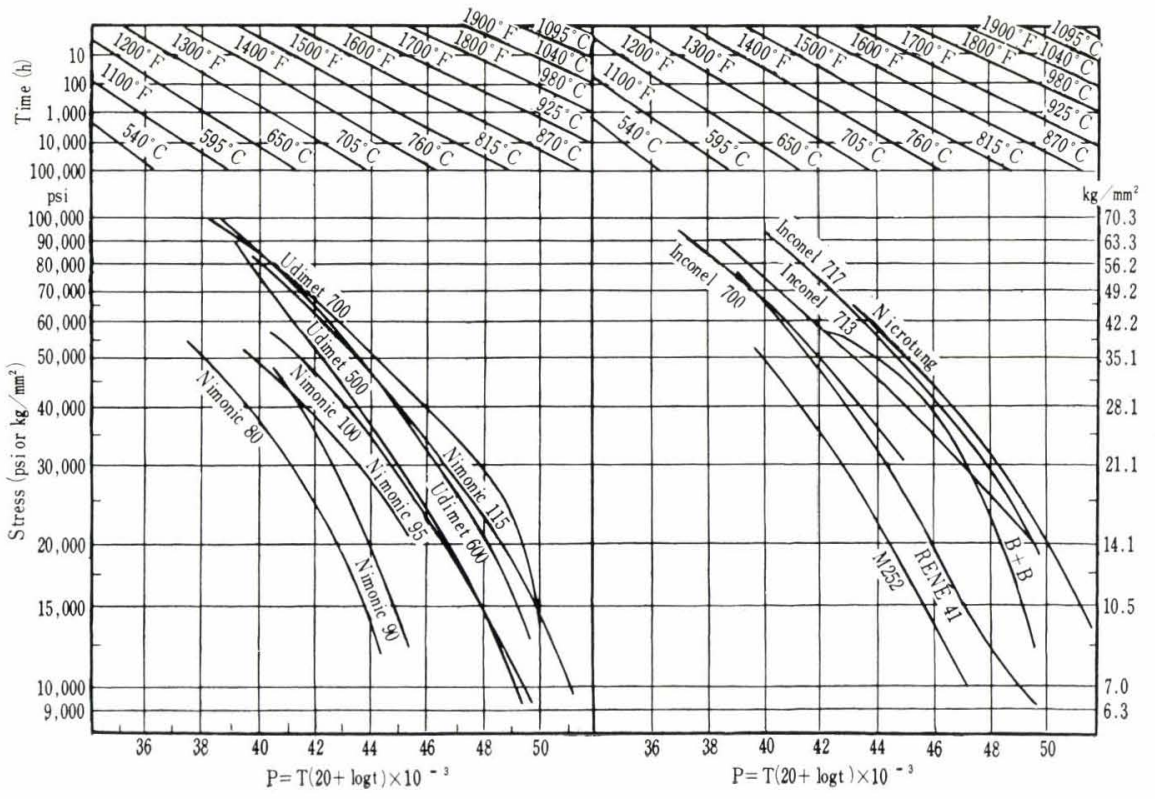

Fig. 3. Stress-rupture diagram of nickelbase heat-resisting alloys 
(4) Addition of boron and carbon

Recently an attempt to raise high-temperature strength as a result of precipitation hardening and strengthening the grain boundaries, etc. by addition of boron to heat-resisting alloys, has been carried out extensively. That is, boron is added to nickel-base heat-resisting alloys such as Nicrotung, $\mathrm{DCM}^{16)}$ and $\mathrm{G} 64,{ }^{17}$ ) etc. Though these alloys to which boron is added have greatly superior hightemperature strength, the forging is so difficult that they are only used as casting alloys. The noticeable tendency of nickel-base heat-resisting alloys is that the carbon content previously having been less than $0.1 \%$ is more than $0.1 \%$ with Nimonic 100, 115 and so on. Thus, creep-rupture strength at high temperature is increased by raising the carbon content.

So far the author has discussed the progress of nickel-base heat-resisting alloys, laying stress on the added elements, and the creep-rupture strength of typical alloys as shown in Table 7 . As a result, the most superior forgeable nickel-base heat-resisting alloy is Nimonic 115 and René 41, etc. These alloys are easily fabricated and welded, and so are being widely used for parts in jet engines. As for casting alloys, there is Nicrotung and Inco 700, etc. In the past, casting alloys were used only in special cases of comparatively small articles and not much was used for ordinary jet engines because of a shortage in reproducibility and a weakness in fatigue strength. However, because the technique of vacuum melting was recently introduced and reliable casting materials have begun to be manufactured, and because the high-temperature characteristics of casting materials are better than those of forging materials (casting materials can be used at temperatures $25-30^{\circ} \mathrm{C}$ higher than forging materials.), and because the forging temperature range of excellent nickel-base heat-resisting alloys for forging is so narrow as to be difficult to manufacture articles of complicated shape (by the addition of titanium, aluminium and boron, etc., the grain boundaries are apt to melt and forging becomes difficult.), nickel-base heat-resisting alloys for casting have come to be used extensively. They are melted in vacuum induction melting furnaces by units of $500-1000 \mathrm{~kg}$, and remelted in vacuum and subjected to precision casting. They can be used for turbine blades, etc.

Table 7 . Rupture strength* of nickel-base heat-resisting alloys

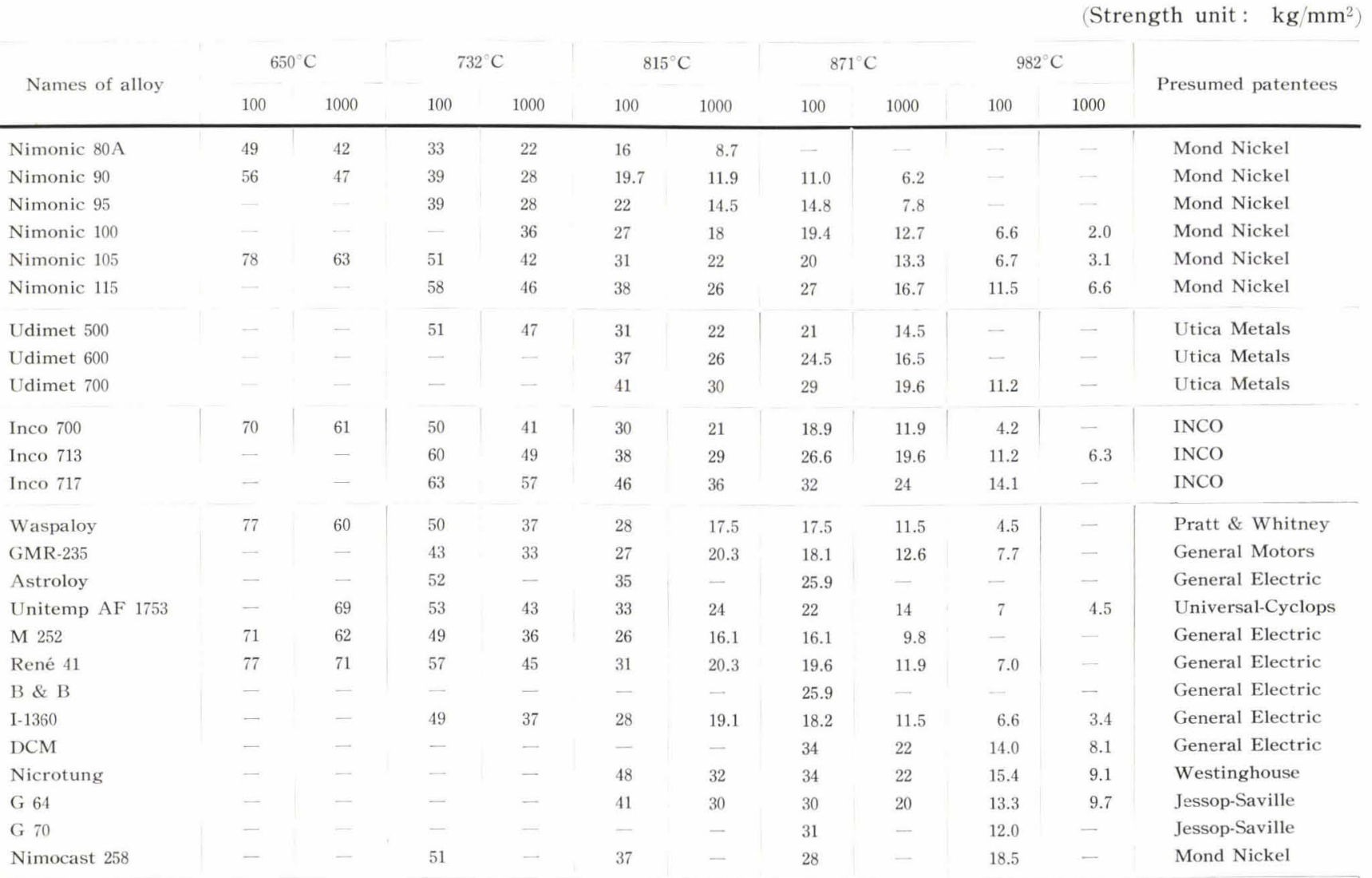




\section{Cobalt-Base Heat-Resisting Alloys ${ }^{18}$}

The chief composition of this type alloy is cobalt; and $20-25 \%$ chromium is added. In addition, Mo, $\mathrm{W}, \mathrm{Ti}$ and $\mathrm{Nb}$, etc. are added, thereby raising the high temperature strength. The chemical composition and rupture strength of typical alloys are shown in Table 8.

There are casting alloys such as HS-31 $(\times 40)$ and HE 1049, etc., and forging alloys such as S 816, G32 and J1570, etc. X40, S816, G32 and so on are alloys precipitating carbide, that is, of a weak precipitation-hardening type, but $\mathrm{J}-1570^{20)}$ and $\mathrm{J}$ 1650 contain much titanium and so cause marked precipitation hardening, as in a nickel-base alloy, and consequently the forging of this alloy is not possible unless the method of vacuum melting is utilized.

For $\mathrm{S} \cdot 816,21)$ the alloying elements of Mo, W and $\mathrm{Nb}$, etc. are added to a cobalt-base alloy, and the stable carbide is precipitated on the austenite matrix. This alloy was used for blades of jet engines some years ago, but nowadays is scarcely used.
Meanwhile G3222) is the superior alloy, obtained as the result of extensive investigation by Jessop Ltd. in the United Kingdom. It has surpassing creep strength in spite of containing a considerable amount of iron $(15 \%)$.

Recently research to obtain high creep strength by adding boron to cobalt-base heat-resisting alloys has been carried out. S816-B, Mod. S816-B ${ }^{23)}$ and HE.1049, which contain great amounts of boron, are examples.

As shown in Table 8, these alloys have a very strong high-temperature strength.

\section{Summary}

The author briefly stated experimental results on some heat-resisting steel alloys, laying stress on the $12 \%$ chromium heat-resisting steels and precipitation-hardening austenitic heat-resisting steels. However, the author has not mentioned some new heat-resisting materials, especially refractory materials, which shall be reserved for future information on another occasion.

Table 8. Chemical composition and rupture strength* of cobalt-base heat-resisting alloys

(Strength unit: $\mathrm{kg} / \mathrm{mm}^{2}$

\begin{tabular}{|c|c|c|c|c|c|c|c|c|c|c|c|c|}
\hline Names of alloy & C & $\mathrm{Mn}$ & $\mathrm{Si}$ & $\mathrm{Cr}$ & $\mathrm{Ni}$ & $\mathrm{Co}$ & Mo & W & $\mathrm{Nb}$ & $\mathrm{Ti}$ & B & $\begin{array}{l}\text { Other } \\
\text { elements }\end{array}$ \\
\hline HS-25 (L 605) & 0.10 & 1.5 & 0.5 & 20 & 10 & Bal. & - & 15 & - & - & - & - \\
\hline HS-31 (X 40) & 0.50 & 0.5 & 0.5 & 25 & 10 & Bal. & - & 7.5 & & & - & - \\
\hline $\mathrm{HE} \cdot 1049$ & 0.40 & 0.8 & 0.8 & 26 & 10 & Bal. & & 15 & - & & 0.40 & - \\
\hline S 816 & 0.40 & 1.2 & 0.4 & 20 & 20 & Bal. & 4.0 & 4.0 & 4.0 & - & & - \\
\hline S $816 \cdot \mathrm{B}$ & 0.40 & 1.0 & 0.4 & 20 & 20 & Bal. & 4.0 & 4.0 & 4.0 & & 1.0 & \\
\hline Mod. S $816 \cdot$ B & 0.40 & 1.0 & 0.4 & 25 & 5 & Bal. & 4.0 & 4.0 & 4.0 & & 1.0 & - \\
\hline M 203 & 0.07 & - & - & 19.5 & 25 & 36 & & 12 & 1.5 & 2.15 & - & $0.75 \mathrm{Al}$ \\
\hline M 205 & 0.07 & - & - & 18.5 & 25 & 38 & & 12 & 1.2 & & 0.22 & $2.75 \mathrm{Al}$ \\
\hline J 1570 & 0.20 & - & - & 20 & 28 & 38 & - & 7.0 & & 4.0 & & - \\
\hline J 1650 & 0.20 & - & - & 19 & 27 & Bal. & - & 12 & & 4.0 & 0.02 & $2.0 \mathrm{Ta}$ \\
\hline Haynes No. 151 & 0.50 & 1.0 & 1.0 & 20 & - & Bal. & - & 13 & - & - & 0.05 & - \\
\hline V 36 & 0.30 & 1.0 & 0.4 & 25 & 20 & Bal. & 4.0 & 2.0 & 2.0 & $\cdots$ & - & - \\
\hline G 32 & 0.28 & 0.8 & 0.3 & 19 & 10 & 42 & 2.2 & - & 1.4 & - & - & $3.0 \mathrm{~V}$ \\
\hline \multirow{2}{*}{ Names of alloy } & \multicolumn{2}{|c|}{$650^{\circ} \mathrm{C}$} & \multicolumn{2}{|c|}{$732^{\circ} \mathrm{C}$} & \multicolumn{2}{|c|}{$816^{\circ} \mathrm{C}$} & \multicolumn{2}{|c|}{$871^{\circ} \mathrm{C}$} & \multicolumn{2}{|c|}{$982^{\circ} \mathrm{C}$} & \multirow{2}{*}{\multicolumn{2}{|c|}{ Presumed patentees }} \\
\hline & 100 & 1000 & 100 & 1000 & 100 & 1000 & 100 & 1000 & 100 & 1000 & & \\
\hline HS-25 (L 605) & 49 & 41 & 30 & 23 & 16 & 12 & 11 & 7.3 & 4.9 & 2.7 & Crucil & e Steel \\
\hline HS-31 (X 40) & 39 & 32 & 31 & 23 & 20 & 16 & 15 & 12 & 6.6 & 4.9 & Gener & 1 Electric \\
\hline $\mathrm{HE} \cdot 1049$ & - & - & - & - & 32 & 25 & 22 & 15.4 & & - & Hayne & Stellite \\
\hline S 816 & 46 & 35 & 28 & 21 & 18 & 13 & 11 & 7.0 & 3.9 & 2.1 & Allegl & ny Ludlum \\
\hline S 816 B & 60 & 55 & - & - & 31 & 22.5 & 21 & 15.7 & 10.2 & 5.5 & Allegl & eny Ludlum \\
\hline Mod. S $816 \cdot$ B & - & - & 52 & - & 34 & - & 25 & - & 10.6 & - & Alleg1 & ny Ludlum \\
\hline M 203 & 59 & 48 & 43 & 28 & 20.7 & 13.1 & - & - & - & - & Gener & Electric \\
\hline M 205 & 55 & 45 & 36 & 26 & 19 & 11.7 & - & - & - & - & Gener & Electric \\
\hline J 1570 & 67 & 55 & 46 & 37 & 23 & 16.8 & 16.1 & 11.2 & - & - & Gener: & Electric \\
\hline J 1650 & - & 57 & 48 & 40 & 32 & 23 & 22.4 & 14.7 & 9.1 & - & Gener & Electric \\
\hline Haynes No. 151 & 51 & 48 & 38 & 34 & 26 & 23 & 18.9 & 16.7 & 9.8 & 8.0 & Hayne & Stellite \\
\hline V 36 & 一 & - & 25 & 19 & 16 & 13 & 11 & 7.7 & 6.0 & 3.5 & Allegl & eny Ludlum \\
\hline G 32 & - & - & 31 & 25 & 20 & 15 & 13 & 9.2 & 4.7 & - & Jessop & Saville \\
\hline
\end{tabular}

* For rupture in 100 and $1000 \mathrm{hr}$ 


\section{REFERENCES}

1) T. Akutagawa: Tetsu to Hagané, 41 (1955), p. 48

2) D.A. Oliver, G.T. Harris: Symp. High Temp. Steels and Alloys for Gas Turbines, the Iron \& Steel Inst. Special Report No. 43. (1952), pp. $46-59$

3) D.L. Newhouse, B.R. Sequin, E.M. Lape: Trans. ASME., 76 (1954) Oct., pp. 1107-1122

4) H.C. Child, G.T. Harris: J. Iron \& Steel Inst. (U.K.), 190 (1958), Dec., pp. 414-431

5) Allegheny Ludlum Blue Sheet: A 286 (United States Patent 2641540)

6) K. Metchlfe: Iron Age, 182 (1958), July, p. 72

7) J.T. Brown: Metal Progress, 74 (1958), Aug., pp. 81-91

8) Materials in Design Eng., 49 (1959), Jan., (Ni Bulletin 1959)

9) Compilation of Chemical Compositions and Rupture Strength of Super-Strength Alloys, ASTM. STP. No. 170-B (1961, Jan)

10) W.W. Dyrkacy: Steel, 138 (1955), Oct. p. 27

11) J.T. Brown: High Temp. Materials, John Wiley \& Sons, New York, pp. 38-55

12 E.E. Reynolds, R.K. Pitler: Iron Age, 183 (1959), 4, pp. $70-71$

13) F.R. Morral : C.I.C. Special Report No. 1 (Jan. 1958)

14) W. Betteridge: Metal Treatment \& Drop Forging, 1956 Sep.

15) W. Betteridge: The Nimonic Alloys., Edward Arnold, London, pp. 32-36

16) J.T. Brown, J.E. Wilson: Metal Progress. 74 (1958), Nov., pp. $83-87$

17) William Jessop and Sons. Ltd.: Vacumelt G 64 Alloy. (Date Sheet Ref. M 743)., 1957

18) F.R. Morral : Alloy for Aircraft Industry, The Role of Cobalt pp. 2336

19) W.O. Sweeny: Trans. ASME., (1947), Aug., pp. 569 581

20) F.T. Chesnut: Metal Progress, 68 (1955), Dec., p. 121

21) T.Y. Wilson: Materials and Methods, 24 (1946), Oct., pp., $885-890$

22) G.T. Harris, H.C. Child: Symp. High Temp. Steels and Alloys for Gas Turbines, The Iron \& Steel Inst. Special Report No. 43 (1952), pp. 67-80

23 W.E. Blatz, E.E. Reynolds, W.W. Dyrkacz: Symp. on Metallic Materials for Service at Temperature above $1600^{\circ} \mathrm{F}$. (ASTM) (1955), pp. $16-28$ 